\title{
ULASAN SYAIR TANGISNYA
}

\section{Fatimahtu Zahroh}

Universitas Nahdlatul Ulama Sidoarjo

\section{A. IDENTITAS PUISI}

Judul puisi

Penulis

Jenis puisi

Bahasa
: Tangisnya

: Agung Purnomo dan Nur Asitah

: Puisi naratif

: Indonesia

\section{B. IDENTITAS BUKU}

Judul buku

: Bhumi Bawera

Penyunting/editor : Kartika Rusnindita

Desainer sampul : Nur Hikam Maulana

Desainer ilustrasi : Alvin Arifin

ISBN

: 978-602-53090-8-3

Penerbit

: STIEBA Madura Press, Sumenep

Tahun terbit

: 2019

Lingkup penerbitan : Nasional

Dimensi

: $15,5 \times 23 \mathrm{~cm}$ 


\section{RESENSI BUKU DAN PUISI}

Berikut adalah potongan puisi berjudul Tangisnya, yakni:

Masih ku dengar suara tangisnya Suara tangis yang teramat sangat menyayat hati Kukira dia Orang yang paling kuat didunia Nyatanya tidak

Puisi berjudul Tangisnya ini ditulis oleh Agung Purnomo dan Nur Asitah, penulis pemula di Malang dan Sidoarjo. Usianya yang masih tergolong muda untuk penulis. Penulis lahir dan besar di kota Sidoarjo.

Penulis Agung Purnomo selain menulis puisi bertajuk Tangisnya (Purnomo \& Asitah, 2019e) juga menulis syair berjudul sebagai berikut: pandai (Purnomo \& Asitah, 2019c), kita (Purnomo \& Rosyidah, 2019), rindu di ubun-ubun (Purnomo, 2019c), sepekan awal tanpamu (Purnomo \& Asitah, 2019d), \#CH1 (Purnomo, 2018a), cantik (Purnomo \& Asitah, 2019b), berpulang (Purnomo, 2019a), Dua kaki (Purnomo, 2018b), bapak Samsuri (Purnomo \& Asitah, 2019a), dan menyala (Purnomo, 2019b). 
Puisi bertajuk Tangisnya termasuk jenis puisi genre puisi naratif yang diterbitkan pada tahun 2019. Puisi Tangisnya ini memaparkan tentang narasi sikap dan perubahan karakter terhadap orang yang lama tak bersua. Puisi ketika dibaca cukup ringan dan enak untuk dibaca. Puisi ini, tampaknya, lebih tepat dan bermanfaat bagi para remaja sedang jatuh cinta dan seseorang yang kangen. Beberapa masukan untuk perbaikan kualitas buku adalah memberikan lebih detail kepada narasi.

Buku antologi puisi berjudul Bhumi Bawera ini terdiri atas beberapa karya puisi dari beberapa penulis. Buku antologi puisi ini membebaskan penulis untuk berkarya tanpa tema tertentu. Cover buku dilaminasi dove sehingga tidak mengkilap ketika dilihat dan di foto.

\section{PENUTUP}

Puisi berjudul Tangisnya di dalam buku antologi puisi bertajuk Bhumi Bawera sangat berguna, khususnya bagi remaja sedang jatuh cinta dan seseorang yang kangen. Sikap dan perubahan karakter terhadap orang yang lama tak bersua. Puisi ketika dibaca cukup ringan dan enak untuk dibaca. Jadi, upaya Agung Purnomo disarankan untuk dinikmati. 


\section{REFERENCES}

Purnomo, A. (2018a). \#CH1. In Kidung Nawala (Jilid 1). Sidoarjo: UNUSIDA Press.

Purnomo, A. (2018b). Dua Kaki. In Kidung

Nawala (Jilid 2). Sidoarjo: UNUSIDA Press.

Purnomo, A. (2019a). Berpulang. In Syair

Nimala. Sumenep: STIEBA Madura Press.

Purnomo, A. (2019b). Menyala. In Tenta Kimaya.

Sumenep: STIEBA Madura Press.

Purnomo, A. (2019c). Rindu di Ubun-Ubun. In

Rassana Jlantir. Sumenep: STIEBA Madura

Press.

Purnomo, A., \& Asitah, N. (2019a). Bapak

Samsuri. In Dhalubang Marta. Sumenep:

STIEBA Madura Press.

Purnomo, A., \& Asitah, N. (2019b). Cantik. In

Lembhar Jiwana. Sumenep: STIEBA

Madura Press.

Purnomo, A., \& Asitah, N. (2019c). Pandai. In

Tolesan Aditi. Sumenep: STIEBA Madura

Press.

Purnomo, A., \& Asitah, N. (2019d). Sepekan

Awal Tanpamu. In Arebhan Helai.

Sumenep: STIEBA Madura Press.

Purnomo, A., \& Asitah, N. (2019e). Tangisnya. In

Bhumi Bawera. Sumenep: STIEBA Madura

Press.

Purnomo, A., \& Rosyidah, E. (2019). Kita. In

Suweda Ate. Sumenep: STIEBA Madura

Press. 